\title{
Pelatihan Kecakapan Masyarakat Dalam Pengembangan Daya Tarik Wisata dan Pemanduan Perjalanan Wisata Desa di Desa Durian Demang Kabupaten Bengkulu Tengah
}

\author{
Anita Marianata ${ }^{17^{*}}$, Dionni Ditya Perdana ${ }^{2}$ \\ 1 Jurusan Administrasi Publik, FISIP Universitas Bengkulu \\ 2 Jurusan Ilmu Komunikasi, FISIP Universitas Bengkulu
}

\section{ARTICLE INFO}

\section{Riwayat Artikel:}

Draft diterima: 10 Oktober 2021

Revisi diterima: 10 November 2021

Diterima: 27 November 2021

Tersedia Online: 26 Desember 2021

Corresponding author:

anitamarianata@gmail.com

Citation: Marianata. A, Perdana. D. D. 2021. Pelatihan Kecakapan Masyarakat dalam Pengembangan Daya Tarik Wisata dan Pemandu Perjalanan Wisata Desa di Desa Durian Demang Kabupaten Bengkulu Tengah. ICOMES: Indonesian Journal of Community Empowerment and Service. 1 (1), pp: 1-5.

\begin{abstract}
ABSTRAK
Pengabdian ini dilakukan di Desa Durian Demang, Kabupaten Bengkulu Tengah. Tujuan dari pengabdian ini meliputi (1) pelatihan kecakapan masyarakat dalam pengembangan daya tarik wisata dan pemanduan perjalanan wisata desa; (2) penambah wawasan bagi masyarakat mengenai pentingnya pengembangan daya tarik wisata dan pemanduan perjalanan wisata desa. Pengumpulan data dilakukan dengan cara observasi, wawancara, dan focus group discussion ( $F G D$ ). Hasil pengabdian menunjukkan Desa Durian Demang melalui BUMDes sudah mengalokasikan untuk pengembangan wisata Bukit Kandis, pembahasan materi dimulai dari kepengurusan desa wisata, tantangan dan peluang desa wisata, dan kesiapan masyarakat untuk berperan aktif dalam keberhasilan desa wisata.
\end{abstract}

Kata kunci: Desa Wisata, Bukit Kandis, Masyarakat Lokal

\begin{abstract}
This activity was carried out in Durian Demang, Bengkulu Tengah Regency. The objectives of this dedication include (1) community skills training in developing tourist attractions and guiding village tours; (2) additional insight for the community regarding the importance of developing tourist attractions and guiding village tourism trips. Data was collected by means of observation, interviews, and focus group discussions (FGD). The results of the service show that Desa Durian Demang through BUMDes has allocated for the development of Bukit Kandis tourism, the discussion of material starts from the management of the tourist village, the challenges and opportunities of the tourist village, and the readiness of the community to play an active role in the success of the tourist village.
\end{abstract}

Keywords: Tourism Village, Bukit Kandis, Local Community

\section{PENDAHULUAN}

Pengembangan pariwisata suatu daerah akan memberikan dampak positif maupun dampak negatif. Dampak tersebut akan berpengaruh terhadap kondisi fisik maupun kehidupan sosial ekonomi penduduk yang berada di sekitar obyek wisata (Soekadijo, 1995). Pariwisata di negara berkembang sering dianggap tidak membawa keuntungan ekonomi yang signifikan, baik bagi negara tujuan maupun bagi masyarakat lokal. Ketimpangan ini terjadi karena sebagian besar usaha pariwisata skala besar dimonopoli oleh pengusaha besar. Usaha pariwisata jenis ini menetapkan berbagai standar tertentu bagi setiap aspek kegiatannya.
Community based tourism merupakan suatu pendekatan pembangunan pariwisata yang menekankan pada masyarakat lokal baik yang terlibat langsung maupun yang tidak terlibat langsung pada industri pariwisata. Hal ini dilakukan dengan bentuk memberikan kesempatan (akses) dalam manajemen dan pembangunan pariwisata yang berujung pada pemberdayaan politis melalui kehidupan yang lebih demokratis termasuk dalam pembagian keuntungan dari kegiatan pariwisata yang lebih adil bagi masyarakat lokal. Gagasan ini disampaikan untuk mengkritisi pembangunan pariwisata yang seringkali mengabaikan peran serta masyarakat lokal di daerah tujuan wisata. 
Konsep community-based tourism merupakan dasar dari sustainable tourism development yang menegaskan bahwa masyarakat bukan lagi menjadi objek pembangunan akan tetapi sebagai penentu pembangunan itu sendiri (Damanik, 2006). Penekanan pada pola kehidupan tradisional merupakan hal penting yang harus dipertimbangkan, mempersiapkan interaksi spontan antara masyarakat dan wisatawan atau pengunjung untuk dapat memberikan pengertian dan pengetahuan pengunjung tentang lingkungan dan kebudayaan setempat selain memberikan rasa bangga masyarakat lokal terhadap kebudayaannya.

Keterlibatan masyarakat dalam pembangunan pariwisata dapat tercermin dalam bentuk kecapakan masyarakat dalam pengembangan daya tarik wisata dan pemanduan perjalanan wisata. Salah satu desa yang telah merintis program pemberdayaan masyarakat melalui pelatihan kecakapan hidup adalah Desa Durian Demang Kecamatan Karng Tinggi Kabupaten Bengkulu Tengah. Selain letaknya yang sangat strategis di jalur lintas antar kota, desa Durian Demang juga memiliki potensi alam yang subur dan hijau dengan perkebunan yang luas dengan latar belakang rangkaian pegunungan menoreh yang indah. Desa Durian Demang memiliki keunggulan lokal berupa budaya dan tradisi yang khas yang juga dapat berpotensi untuk disajikan dalam mendukung sektor industri pariwisata. Mata pencaharian penduduk di desa Durian Demang ratarata sebagai petani.

Mayarakat desa Durian Demang telah menyadari potensi wisata alam yang dapat ditawarkan di wilayah Desa yaitu adanya Bukit Kandis (bukit bebatuan). Adapun potensi wisata alam yang ada di Desa Durian Demang, yaitu:.

\section{a. Panjat Tebing}

Bukit yang masih tersisa kerap dimanfaatkan pecinta alam sebagai sarana climbing, untuk menjaga keutuhan bukit maka perlu perawatan pengorganisasian wilayah yang dapat dimanfaatkan sebagai arena panjat tebing.

\section{b. Area Fotografi (Pre-Wedding, art photography)}

Keindahan pemandangan yang ditawarkan Bukit Kandis telah menarik orang-orang untuk melakukan sesi pemotretan di area tersebut. Dengan memfasilitasi tempat melakukan kegiatan fotografi diharapkan dapat semakin mengenalkan Bukit Kandis secara viral dan warga pun memiliki pemasukan.

\section{c. Camping Ground}

Arena yang masih terbilang luas dengan pemandangan yang indah merupakan tempat yang cocok untuk dijadikan camping ground. Wisata ini dapat menyasar siswa, mahasiswa maupun pekerja kantoran yang memiliki kegiatan keakraban dan sebagainya.

\section{d. Outbound}

Guna mendukung kemenarikan Bukit Kandis sebagai objek wisata, maka perlu dilengkapi dengan fasilitas outbound agar wisatawan dapat berkegiatan bukan hanya menikmati pemandangan.

\section{e. Off-Road}

Perlombaan off-road pernah digelar di Bukit Kandis oleh pemerintah daerah setempat. Lokasi yang sangat mendukung kemudian diikuti masyarakat yang ramai untuk menyaksikan menjadikan off-road sebagai salah satu pilihan berwisata di Bukit Kandis.

\section{f. Terbang Layang}

Poin keenam ini muncul terakhir dalam diskusi. Mengingat perlu adanya tahapan dalam mengembangkan objek wisata, terbang layang dianggap memerlukan pemikiran yang lebih panjang karena memerlukan kesiapan sarana dan prasarana yang sangat mendukung.

Adanya potensi wisata tersebut, menuntut kecapakan masyarakat dalam pengembangan pariwisata dan juga masyarakat harus siap dan mampu dalam memandu wisata bagi para wisatawan yang akan berkunjung ke tempat wisata yang ada di Desa Durian Demang, Kecamatan Karang Tinggi, Kabupaten Bengkulu Tengah.

\section{METODE PELAKSANAAN}

Metode yang digunakan dalam melaksanakan pengabdian pada masyarakat akan menggunakan pendekatan kualitatif deskriptif. Adapun metode pengumpulan data dalam penelitian ini dimaksudkan untuk memperoleh data yang relevan dan akurat dengan masalah yang dibahas. Metode pengumpulan data tersebut adalah sebagai berikut:

\section{Observasi}

Observasi adalah metode dipergunakan sebagai salah satu piranti dalam pengumpulan data berdasarkan pengamatan secara langsung Desa Durian Demang Kecamatan Karang Tinggi Kabupaten Bengkulu Tengah.

\section{Wawancara}

Wawancara yaitu dialog secara langsung untuk memperoleh informasi dari informan terpilih dalam menghimpun informasi yang relevan dengan pengabdian yang akan diadakan di Desa Durian Demang Kecamatan Karang Tinggi Kabupaten Bengkulu Tengah. 


\section{Focused Group Discussion (FGD) atau Rembuk Masyarakat}

Dengan menggunakan tehnik pengumpulan data melalui observasi dan juga dialog antara Tim Pengabdian Dosen dengan masyarakat, dan pemberian pengarahan dalam penguatan partisipasi masyarakat dan pelatihan kecakapan masyarakat dalam pengembangan daya tarik wisata dan pemanduan perjalanan wisata desa.

\section{HASIL DAN PEMBAHASAN}

Pelaksanaan kegiatan Pengabdian kepada Masyarakat di Desa Durian Demang dilakukan pada bulan Juli s/d Agustus tahun 2019, dengan rincian kegiatan sebagai berikut:

Tabel 1. Rincian Pelaksanaan Kegiatan PPM di Desa Durian Demang Tahun 2019

\begin{tabular}{|c|c|c|}
\hline Tanggal & Jenis Kegiatan & $\begin{array}{c}\text { Lokasi } \\
\text { Kegiatan }\end{array}$ \\
\hline 20 Juni 2019 & $\begin{array}{l}\text { Diskusi awal dengan } \\
\text { pengelola, } \\
\text { masyarakat, dan } \\
\text { pejabat Desa Durian } \\
\text { Demang tentang } \\
\text { pelaksanaan } \\
\text { kegiatan PPM }\end{array}$ & $\begin{array}{c}\text { Kantor Desa } \\
\text { Durian } \\
\text { Demang }\end{array}$ \\
\hline 26 Juni 2109 & Pelatihan Pemandu & $\begin{array}{l}\text { Desa Durian } \\
\text { Demang }\end{array}$ \\
\hline 10 Juli 2019 & Praktik Memandu & $\begin{array}{c}\text { Desa Durian } \\
\text { Demang }\end{array}$ \\
\hline 31 Juli 2019 & $\begin{array}{l}\text { Kegiatan } \\
\text { Pendampingan dan } \\
\text { Penyusunan } \\
\text { Laporan }\end{array}$ & $\begin{array}{c}\text { Desa Durian } \\
\text { demang dan } \\
\text { UNIB }\end{array}$ \\
\hline 14 Agustus 2019 & Seminar Akhir PPM & $\begin{array}{c}\text { Aula Desa } \\
\text { Durian } \\
\text { Demang }\end{array}$ \\
\hline $\begin{array}{c}\text { 4 September } \\
2019\end{array}$ & Evaluasi & $\begin{array}{c}\text { Desa Durian } \\
\text { Demang dan } \\
\text { UNIB }\end{array}$ \\
\hline
\end{tabular}

Adapun hasil pelaksanaan kegiatan Pengabdian kepada Masyarakat di Desa Durian Demang, adalah sebagai berikut:

1. Pengelola, masyarakat, dan pejabat desa setempat merasa puas dengan diadakannya pelatihan pemanduan wisata di Desa Durian Demang oleh Tim Pengabdi dari FISIP UNIB. Indikator tingkat kepuasaan peserta kegiatan dapat dilihat dengan adanya permintaan untuk dilakukannya pendampingan terhadap pemandu wisata Desa Durian Demang.
2. Pelatihan pengembangan materi pemanduan wisata, pelatihan metode melatih pemandu, praktik melayani wisatawan, dan evaluasi.

3. Usulan yang diajukan oleh pihak pengelola Desa Durian Demang adalah penambahan pendampingan pamandu wisata.

Diskusi awal. Pada tahap diskusi awal, tim menemui beberapa stakeholder dari Desa Durian Demang, yakni Kepala Desa, Aparatur Desa dan Juga Perwakilan BPD. Pada pertemuan tersebut membicarakan mengenai potensi pengembangan pariwisata Bukit Kandis dan kesiapan warga desa Durian Demang untuk menjadi pemandu wisata. Dari pertemuan awal tersebut, kami mengetahui bahwa potensi wisata di Bukit Kandis sangat menjanjikan untuk menjadi sumber pendapatan desa. namun, belum ada legalitas yang mengikat tentang pengelolaan Bukit Kandis membuat usaha untuk menjadikan desa wisata tidak maksimal. Desa Durian Demang melalui BUMDes sudah mengalokasikan untuk pengembangan wisata Bukit Kandis. Dari penjelasan kepala desa, meskipun kesadaran akan desa wisata sudah terbangun pada beberapa warga, seperti pengurus desa, namun beberapa anggota masyarakat lainnya belum memahami akan hal tersebut. Kepala desa ingin pada pelatihan juga dibahas mengenai bagaimana kekompakan dalam menyukseskan desa wisata Durian Demang.

Pelatihan Pemanduan. Pada pertemuan selanjutnya, tim memberikan pelatihan kepada warga desa Durian Demang dan perangkat desa baik itu kepala dusun maupun karang taruna. Pelatihan tersebut diisi langsung oleh ketua dan anggota pengabdian. Pada pelatihan, pembahasan materi dimulai dari kepengurusan desa wisata, tantangan dan peluang desa wisata, dan kesiapan masyarakat untuk berperan aktif dalam keberhasilan desa wisata.

Pendampingan.

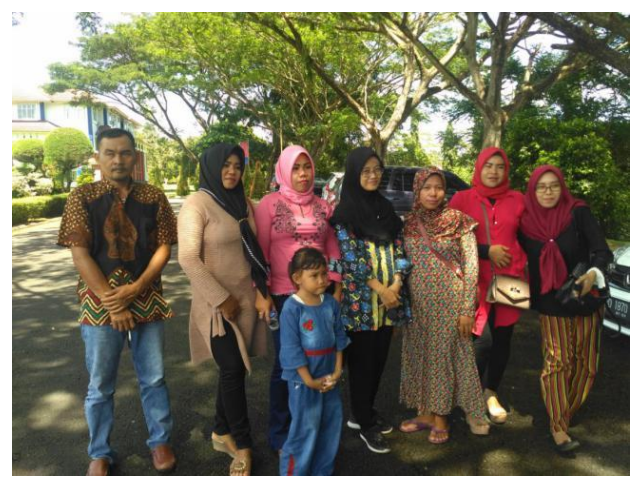

Gambar 1. Kegiatan Pendampingan Warga Durian Demang Di Universitas Bengkulu 


\section{Pembahasan Hasil Pelaksanaan Kegiatan PPM}

Permasalahan yang terdapat dalam kegiatan Pengabdian Kepada Masyarakat khususnya pada pelatihan pemandu wisata, adalah peserta memiliki latar belakang pengetahuan yang heterogen baik dari aspek pendidikan maupun keterampilan. Permasalahan tersebut merupakan salah satu faktor penghambat pada setiap penyelenggaraan pelatihan. Untuk itu, dalam pelatihan ini kendala tersebut diatasi dengan cara sebagai berikut: 1 . Pemberian materi teori dilakukan secara berkelompok dengan cara mengkolaborasikan anggota kelompok dari latar belakang pendidikan dan keterampilan yang berbeda. 2. Materi praktik diberikan dengan menggunakan metode demonstrasi dan drill secara klasikal. 3. Untuk mengetahui tingkat keberhasilan pelatihan, diadakan praktik memandu wisata pada wisatawan secara langsung dengan sistem pendampingan.

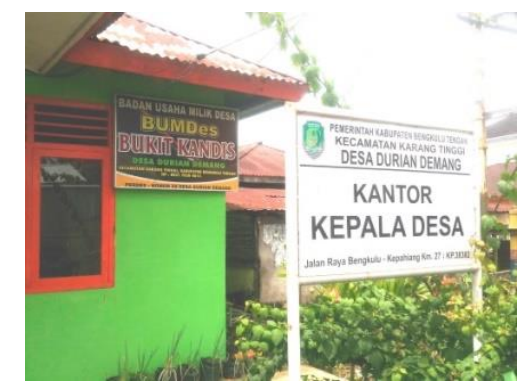

Gambar 2 Kantor Desa Durian Demang

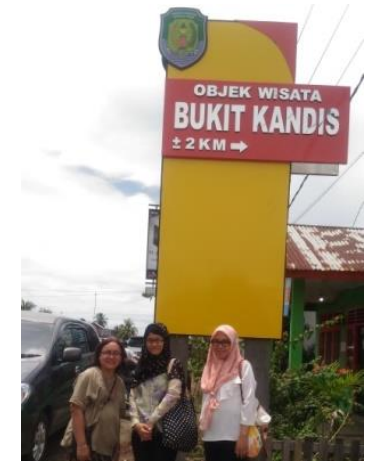

Gambar 3 Gerbang Masuk Wisata Bukit Kandis

Meskipun beberapa kendala muncul selama kegiatan berlangsung, namun semua dapat diatasi dengan baik. Keberhasilan dalam mengatasi setiap permasalahan sangat didukung adanya kerjasama yang baik antara Tim Pengabdi, pengelola desa wisata, warga masyarakat, dan pejabat desa setempat. Adapun faktor yang berperan terhadap keberhasilan pelaksanaan kegiatan, di antaranya sebagai berikut: 1. Kesiapan dan motivasi, serta tanggapan positif dari pengelola, pejabat desa, dan warga masyarakat setempat merupakan modal dasar untuk mengembangkan desa wisata. Mereka menyadari bahwa partisipasi aktif dari pihak desa wisata setempat, kerjasama, permintaan bantuan dari berbagai pihak, dan tahapan merupakan hala yang perlu dilakukan. 2. Materi pengarahan/pembinaan dapat diterima oleh khalayak sasaran dengan memuaskan oleh karena dirancang berdasarkan hasil survei dan diskusi yang dilakukan oleh Tim Pengabdi dengan khalayak sasaran. 3. Permasalahan yang diajukan dan ditemukan dalam pertemuan merupakan permasalahan yang sesuai dengan arah pengembangan dan hasil diskusi dengan khalayak sasaran. 4. Pengembangan pemanduan wisata di Desa Durian Demang layak untuk dilakukan, mengingat wilayah tersebut memiliki potensi alam yang mendukung serta memiliki sumber daya manusia yang dapat dididik sebagai pemandu wisata.

\section{KESIMPULAN}

Berwisata menjadi salah satu kebutuhan masyarakat pada era ini. Daerah-daerah di Indonesia memiliki potensi yang menjanjikan sebagai destinasi wisata. Wisata pun dapat beragam, mulai dari wisata alam, wisata sejarah dan wisata budaya. Desa wisata tengah banyak dikembangkan di berbagai daerah di Indonesia, kekayaan budaya serta adat istiadat ditambah keindahan alam yang masih terjaga membuat banyak wisatawan tertarik untuk datang.

Masyarakat pun memandang desa wisata menjadi bisnis yang menguntungan bagi desa. Masyarakat lokal sudah seharusnya terlibat langsung dalam program tersebut. Tidak hanya menikmati peningkatan pendapatan daerah dari sektor pariwisata, lebih dari itu masyarakat lokal adalah subjek dalam pengembangan pariwisata. Begitu pun desa wisata Durian Demang yang menggunakan Bukit Kandis sebagai ikon wisata yang ditawarkan.

Pengembangan desa wisata adalah ide yang tepat dan dampaknya dapat dirasakan langsung oleh masyarakat lokal. Peningkatan kapasitas berfikir masyarakat akan membantu dalam menciptakan desa wisata yang menarik wisatawan. Desa wisata membuat masyarakat lokal aktif menjaga "asset" yang dimilikinya, baik itu sumber daya alam maupun kebudayaan yang disajikan untuk dilanggengkan eksistensinya.

\section{UCAPAN TERIMAKASIH}

Terimakasih kepada Universitas Bengkulu, yang telah memberikan kesempatan dalam melaksanakan kegiatan pengabdian pada Pengabdian Pembinaan 2019 Pendanaan Negara Bukan Pajak Universitas Bengkulu Tahun Anggaran 2019.

\section{DAFTAR PUSTAKA}


Damanik, Janianton dan Weber, Helmut F. 2006.

Perencanaan Ekowisata: dari Teori ke Aplikasi. Yogyakarta: Penerbit Andi.

Pemprov Bengkulu Tetapkan Program Visit 2020 Wonderful Bengkulu, Minggu, 12 Nov 2017 20:39 WIB. https://travel.detik.com/advertorial-news-blocktravel/d-3724069/pemprov-bengkulu-tetapkanprogram-visit-2020-wonderful-bengkulu

Soekadijo, R.G. 1995. Anatomi Pariwisata: Memahami Pariwisata Sebagai System Linkage. Bandung: Angkasa. Risman, Apep. Wibhawa. Budhi., Fedryansyah. M. 2016.

Kontribusi Pariwisata terhadap Peningkatan Kesejahteraan Masyarakat Indonesia. Prosiding KS: Riset dan PKM, vol.3 no.1 ISSN: 2442-4480. 